Boise State University ScholarWorks

$7-1-2013$

\title{
Louis Fisher on the Constitution and the War Power
}

David Gray Adler

Boise State University 


\title{
Louis Fisher on the Constitution and the War Power
}

\author{
David Gray Adler, Boise State University
}

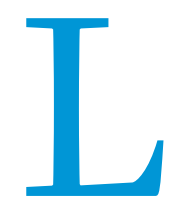

ou Fisher's prolific writings on the war powerthe constitutional repository of authority to initiate war and lesser military hostilities on behalf of the American people-have informed and, for the better part of four decades, shaped discussions and debates on the respective roles of Congress and the president, from the halls of academe to the corridors of power. Widely cited and invoked on hundreds of occasions by political scientists, historians, and legal academics, his work has opened doors for serious consideration of his views by representatives in all three branches of the federal government. It has, as well, established his place in the front-rank of constitutional scholars and, almost certainly, earned for his scholarship an enduring influence on discussions about the constitutional authority to order the use of military force.

Fisher's thesis is clear and convincing. The War Clause of the Constitution, which provides that "Congress shall have Power... To declare War," vests in Congress the sole and exclusive authority to initiate all military hostilities on behalf of the American people (Art. I, Sec. 8). The president, in his capacity as commander in chief, has the authority to repel invasions of the United States, and the power to conduct war once declared or otherwise authorized by Congress, but possesses no constitutional power to authorize the use of force. Until 1950, no president had asserted a unilateral executive power to initiate war. Beginning, however, with Harry Truman's decision to deploy troops to Korea-without congressional authorization-every president except Dwight Eisenhower has laid claim to a presidential war power. As a result, Americans have witnessed, for the past half century, a string of presidential wars in direct violation of the War Clause of the Constitution. As Fisher has written, "[ $t]$ he drift of the war power from Congress to the President after World War II is unmistakable" (Fisher 2004, 261).

Fisher's penetrating analysis of the purported legal bases of executive war making, including his examination of textual assertions of a presidential power to initiate military hostilities, have thoroughly discredited executive branch efforts to circumvent congressional authorization-the sine qua non for the constitutional use of force. Thus, the president has neither an extra-constitutional nor an inherent power to wage war (Fisher 2004, 20-22, 69-73; Fisher 2007a, 1-22; Fisher 2007b, 139-52). Presidential resort to an act of authorization of military force by an international organization such as the United Nations or NATO, is unavailing because treaties, which are made by the president and Senate and do not include a role for the House of Representatives, fall short of the constitutional requirement of an affirmative vote by both houses of Congress (Fisher 1997, 1237-279; Fisher 2004, 81-99, 105-14,
169-74, 175-201; Fisher 2012, 176-89). Policy arguments, not grounded in the Constitution, have no currency. At all events, the Constitution requires congressional authorization for the use of military force.

Presidential usurpation of the war power, like congressional abdication of its constitutional duty to decide on matters of war and peace, has grave consequences. It poses, as Fisher has observed, "a threat to constitutional government, civil liberties, and national security" at home and abroad. "It represents, moreover, the culmination over the past 50 years of unilateral presidential wars accompanied by few checks from Congress or the judiciary. Academics, the media, and the general public have shown little understanding of constitutional limits and little interest in keeping the president within legal bounds" (Fisher 2006, 23-52).

Indifference to presidential war making, however, does not diminish its danger to constitutional values, republican principles, and the national interest. As Fisher has pointed out, President Lyndon Johnson feared the impact on his own political fortunes of a decision he might make to withdraw the United States from Vietnam, despite his conclusion that the war was unwinnable. He feared being labeled soft on communism. Moreover, "[i] nstead of formulating a plan for the national interest," Fisher noted, Johnson determined to lie "'in the pursuit of self-interest'" (Fisher 2000, 51; Fisher 2006, 25). Misleading statements, and outright deception by presidents, including James K. Polk, Harry S. Truman, Ronald Reagan, and George W. Bush, among others, run deep in our history, as Fisher has written, and underscore the dangers of unilateral presidential war making (Fisher 2010, 171-84).

Fisher's consistent defense of congressional control of the war power rests on constitutional principles, not on partisan concerns, and certainly not on a naïve assumption that Congress will always reach a wise or correct decision. He is not so much "pro-Congress" as he is "pro-Constitution." Indeed, he has been critical of Congress for its abdication and surrender of its constitutional power and responsibility to make decisions on matters of war and peace. In the wake of presidential aggrandizement of the war power in the Vietnam War, for example, Congress might have revived and defended its constitutional authority over matters of war and peace. "Instead of reasserting congressional power, the War Powers Resolution marked an abject surrender of legislative prerogatives to the president" (Fisher 2000, 13; Fisher and Adler 1998, 1-20). Still, he embraces the idea that wiser decisions in foreign, as in domestic affairs, are made through reliance on checks and balances, shared decision making and the cross-fire of debate by the nation's representatives. His position certainly finds 
support in the historical record that reveals the flaws of unilateral executive actions, grounded in misperception, poor judgment, political motives and ambition, and faulty intelligence, not to mention acts of presidential deception (Fisher 2000, 51-66; Fisher 2004, 202-35; Fisher 2010, 171-84).

Fisher's defense of the constitutional principles that govern the use of military force, reflective of a nonpartisan analysis, has won, at various times, praise and commendation from both Republicans and Democrats on Capitol Hill. Presidential usurpation of the war power, often the target of Fisher's criticisms, has not endeared him to the executive branch. Occasionally, however, executive officials, with the benefit of hindsight, have belatedly and, perhaps surprisingly, embraced Fisher's scholarly conclusions. Former White House Counsel to President Richard Nixon, John Dean, whose own critical works on the abuse of power have earned for him redemption and considerable respect from previous critics, has justly characterized Fisher's highly acclaimed, best-selling Presidential War Power, as the premier book on the subject (Dean 2007, 314).

On publication of the first edition of Presidential War Power (1995), the distinguished historian, Theodore Draper, wrote for the New York Times Book Review a trenchant and enthusiastic critique of the book. Draper exalted Fisher's success in refuting the claims by US presidents of a unilateral executive power to initiate military hostilities. He observed that ever since the Korean War, "Presidents have been violating the Constitution of the United States," and declared that Fisher "had taken on all of the Presidents and their lawyers who have contrived for almost half a century to offer excuses for autonomous Presidential war-making." Draper described Fisher's book as "a hygienic effort to bring us back to the law" (Draper 1995, 1).

Fisher's works on the war power, like his many other books and some 400 articles on a variety of constitutional issues, have been written in characteristically lean and lucid prose with a clarity rarely achieved among academics. They reflect clear premises, thorough and illuminating archival research, balanced analysis, and conclusions grounded in and directed by the evidence. His framework for analysis taps the cornerstones of convention for legal scholars: constitutional text, debates in the Constitutional and State Ratifying Conventions, commentary contemporaneous with the framing of the Constitution, governmental practice in the early years of the republic, and judicial rulings. He has, as the New York Times observed, taken on "all comers" and come to grips with views and arguments of scholars and government officials who have advanced the claim of a unilateral presidential authority to commence war.

\section{CONSTITUTIONAL CONVENTION DEBATES}

We can learn a great deal about the work of the Constitutional Convention, not merely from what was done there, but also from what was said. The War Clause grants to Congress power "to Declare War." Article 2, Section 2 of the Constitution declares: "The President shall be Commander in Chief of the Army and Navy of the United States, and of the Militia of the several States, when called into the actual Service of the
United States." To the extent that these provisions may require reconciliation, Fisher turns to the debates in the Philadelphia Convention. They reveal, Fisher wrote in Presidential War Power, "that the framers were determined to circumscribe the President's authority to take unilateral military actions" (Fisher 2004,8 ). The nature of the debates on the power to initiate war leave no doubt that the framers vested that authority in Congress alone.

Fisher's unerring narration of the Convention debates is clear and efficient. An early draft had empowered Congress to "make war." On August 17-the second, final, and most significant day of debate on the war power, which coincidentally falls on Fisher's birthday although he claims not to have been present at the creation-Charles Pinckney objected that legislative proceedings were "too slow" for the safety of the country in an emergency, because he expected Congress to meet but once a year. James Madison and Elbridge Gerry, in a joint motion, proposed to substitute "declare" for "make," leaving to the president "the power to repel sudden attacks." Their motion carried on a vote of 7 to 2 . When Rufus King explained that the word "make" would allow the president to conduct war, which was an "Executive function," Connecticut changed its vote and the final tally became 8 to 1 (Fisher 2004, 3-6;10; Farrand 1966, 2: 318-19).

The meaning of the debate was unmistakable. Congress, alone, would possess the authority to initiate war; the president would exercise authority to repel invasions. Because invasion represented a grave emergency, the president, in his capacity as Commander in Chief, was empowered "to take actions necessary to resist sudden attacks either against the mainland of the United States or against American troops abroad." But the president, Fisher observed, "never received a general power to deploy troops whenever and wherever he thought best, and the framers did not authorize him to take the country into full-scale war or to mount an offensive attack against another nation." That was the sole province of Congress (Fisher 2004, 8-9).

The framers' decision to assign the war power to Congress, rather than the president, represented a dramatic rejection of the executive model for war and foreign affairs, a design practiced in England and the world over. Delegates, as Fisher explains, were familiar with the fact that kings and despots and tyrants had often marched their people into war, for less than meritorious reasons, and usually for their own personal or political motivations. Given the framers' emphasis on collective decision making, and their rejection of executive unilateralism, the Convention, as James Wilson of Pennsylvania declared, was designed to prevent one man from hurrying "us into war." On the contrary, "it is calculated to guard against it. It will not be in the power of a single man, or a single body of men, to involve us in such distress; for the important power of declaring war is vested in the legislature at large" (Elliot 1836, 2: 528; Fisher 2004, 9).

By the end of the Convention, no delegate was on record as supporting the concept of a unilateral executive power to initiate war or military hostilities. Indeed, during the course of debates, only one man, Pierce Butler, wanted to vest the war power in the president whom, he argued, "will have the 
requisite qualities, and will not make war but when the Nation will support it." The framers, as Fisher wrote, "uniformly rejected his proposal." Give Butler credit for being a quick study. He took his lumps from delegates who were shocked, as Elbridge Gerry put it, because "he never expected to hear in a republic a motion to empower the Executive alone to declare war." But by the end of the debate on August 17, Butler not only reversed his position, but introduced a measure on the floor that would vest in the legislature the authority to end war, just as it enjoyed the authority to initiate war. In the South Carolina Ratifying Convention, Butler told his fellow delegates that a particular delegate had had the temerity to propose a presidential war power but that the delegates had rejected the idea. He made no mention of the name of the author of that proposal (Fisher 2004, 9; Adler 2003, 972-73).

\section{INFLUENCES ON THE CONVENTION}

The Convention's constitutional design for initiating war, as Fisher has demonstrated, was shaped in large measure by the framers' commitment to republican governance, which empha-
Articles of Confederation warned that "nations in general will make war whenever they have a prospect of getting anything by it; nay, absolute monarchs will often make war when their nations are to get nothing by it, but for purposes and objects merely personal, such as a thirst for military glory, revenge for personal affronts, ambition, or private compacts to aggrandize or support their particular families or partisans. These and a variety of other motives, which affect only the mind of the sovereign, often lead him to engage in wars not sanctified by justice or the voice and interests of his people" (Fisher 2004, 10).

Jay's insights echoed throughout the early years of the republic. Madison, for example, wrote in 1793, that war is "the true nurse of executive aggrandizement... In war, the honors and emoluments of office are to be multiplied; and it is the executive patronage under which they are to be enjoyed. It is in war, finally, that laurels are to be gathered; and it is the executive brow they are to encircle. The strongest passions and most dangerous weaknesses of the human breast; ambition, avarice, vanity, the honourable or venial love of fame, are

\section{The framers' decision to assign the war power to Congress, rather than the president, represented a dramatic rejection of the executive model for war and foreign affairs, a design practiced in England and the world over. Delegates, as Fisher explains, were familiar with the fact that kings and despots and tyrants had often marched their people into war, for less than meritorious reasons, and usually for their own personal or political motivations.}

sized shared decision making and checks and balances, and rejected unilateral executive power. The delegates' deepseated fear of executive power, born of their own experience and their reading of history, led them to break from the monarchical model that governed England and much of the world and that placed in the hands of the executive sole authority over matters of war and national security. The framers, as Fisher has explained, dramatically rejected the "executive model" and granted to Congress, not the president, exclusive control over the decision to go to war as well as the lion's share of foreign affairs authority. The Convention's blueprint was admirably summed up by James Madison in words that Fisher views as authoritative: "Those who are to conduct a war cannot in the nature of things, be proper or safe judges, whether a war ought to be commenced, continued, or concluded. They are barred from the latter functions by a great principle in free government, analogous to that which separates the sword from the purse, or the power of executing from the power of enacting laws" (Fisher 2004, 11).

History and experience provided a valuable guide to the Convention. "In their study of past governments," Fisher wrote," the framers understood that executives, in search of fame and glory, had an appetite for war" (Fisher 2006, 25). Fisher's conclusion is grounded in John Jay's insights in Federalist No. 4, where the Secretary of Foreign Affairs under the all in conspiracy against the desire and duty of peace." Five years later, as Fisher observed, Madison wrote to Thomas Jefferson that the Constitution "supposes, what the History of all Govts demonstrates, that the Ex. is the branch of power most interested in war, \& most prone to it. It has accordingly with studied care, vested the question of war in the Legsl" (Fisher 2004, 10).

\section{THE EARLY REPUBLIC}

The understanding of the Convention, as Fisher has described it, was embraced by the various state ratifying conventions, and affirmed in the Federalist Papers, government practice, and judicial decisions in the early period of the republicwithout dissent. The ratifiers' understanding of the allocation of the war power was illuminated in North Carolina, where James Iredell, soon to be a member of the US Supreme Court, distinguished, in words that reflected Alexander Hamilton's analysis in Federalist No. 69, the limited authority of the president with that of the English monarch. The English King, wrote Iredell, was not only Commander in Chief "but has power, in time of war, to raise fleets and armies. He also has authority to declare war." In contrast, the president "has not the power of declaring war by his own authority, nor that of raising fleets. Those powers are vested in other hands. The power of declaring war is expressly given to Congress." In 
South Carolina, Charles Pinckney assured his colleagues that the "President's powers did not permit him to declare war" (Fisher 2004, 9-10).

\section{EARLY PRACTICE}

Over the past half-century, proponents of an executive war power have sought to ground their claims in historical precedent, by asserting that early presidents had unilaterally authorized the use of military force. The compilation of lists of purported instances of presidential war making, however, represents little more than an exercise in revisionism that is betrayed by the historical record. Fisher's thorough examination of the practice of going to war in the early republic has affirmed, and extended, previous historical analyses that have discredited executive branch assertions of unilateral presidential war making (Adler 1988, 17-26, 35-36; Fisher 2004, 17-55; Wormuth and Firmage 1986, 133-150). Fisher has demonstrated that early presidents-George Washington, John Adams, and Thomas Jefferson-adhered to the constitutional design and advanced no claims of a unilateral presidential power to initiate military hostilities. Washington, for example, refused to order the use of force against an Indian tribe in 1792 , on the ground that authority to commence hostilities is constitutionally granted to Congress. In the Quasi- it is for Congress, alone, to decide whether a war should be "perfect" or "imperfect," that is, general or limited. In addition, it is for Congress, not the president, to decide where war may be waged, and whether it might be "limited in place, in objects, and in time." In Bas, the Court held that Congress had authorized "hostilities on the high seas by certain persons in certain cases." There was no "authority given to commit hostilities on land," a stricture that sharply limited the discretion of the Commander in Chief to conduct war (Bas v. Tingy, 43).

Chief Justice John Marshall affirmed the sweep of congressional authority the following year, in Talbot v. Seeman: "The whole powers of war being, by the constitution of the United States, vested in congress, the acts of that body can alone be resorted to as our guides in this inquiry" (Talbot v. Seeman 1801, 28).

The teaching of these cases, like the Court's ruling in Little v. Barreme in 1804, is clear. Fisher has justly stated: "Those cases do not imply that once Congress authorizes war, the President is at liberty to choose the time, location, and scope of military activities. In authorizing war, Congress may place limits on what presidents may and may not do" (Fisher 2004, 25). In fact, the Court in Barreme, in another opinion delivered by Marshall, held that the president is bound to obey

\section{Fisher's painstaking demolition of the contrived lists of presidential wars in the early republic has undermined efforts by scholars and officials to invoke historical practice as an ally. The fact that the early practice of decision making on matters of war and peace conforms to the constitutional design has forced revisionists to seek support elsewhere.}

War with France, 1798-180o, Congress enacted two dozen statutes authorizing the use of force. Adams made no assertion of a presidential power to initiate hostilities. As president, Jefferson was challenged by the attacks of pirates of Tripoli on US commercial vessels sailing in the Mediterranean. As tempting as it might have been to authorize the initiation of force against the pirates, Jefferson was yet mindful of the constitutional distinction between offensive acts, which are within the province of Congress, and defensive acts, which are within the realm of presidential power (Fisher 2004, 17-36).

Fisher's painstaking demolition of the contrived lists of presidential wars in the early republic has undermined efforts by scholars and officials to invoke historical practice as an ally. The fact that the early practice of decision making on matters of war and peace conforms to the constitutional design has forced revisionists to seek support elsewhere.

\section{JUDICIAL PRACTICE}

As Fisher has shown, several judicial decisions arising out of the Quasi-War that were rendered by the Supreme Court at the dawn of the republic held that Congress possesses, as Madison observed, sweeping authority to "commence, conclude and continue" war. In Bas v. Tingy (180o), the Court held that statutory commands imposed by Congress in the conduct of war (Little v. Barreme, 179). Two years later, that lesson was reaffirmed in United States v. Smith (1806), in an opinion written by Justice William Paterson, a member of the Constitutional Convention, while riding circuit. In words that have erected a platform for Fisher, Justice Paterson declared: "The President of the United States cannot control the statute nor dispense with its execution, and still less can he authorize a person to do what the law forbids. If he could, it would render the execution of the laws dependent on his will and pleasure; which is a doctrine that has not been set up, and will not meet with any supporters in our government" (United States v. Smith, 1230, quoted in Fisher 2004, 25-26, 29-31; Fisher 2005, 469-71). These decisions have never been overturned and remain good law.

\section{CONTEMPORARY POLICY JUSTIFICATIONS}

Advocates of a unilateral presidential authority to decide on matters of war and peace have advanced various policy arguments to defend the shift of power from Congress to the president. As Fisher has observed, they tend to focus on "the need for secrecy and prompt action, qualities supposedly associated in some unique fashion with the Executive." These arguments, he concludes, have but "a superficial allure" (Fisher 2004, 261). Fisher rightly dismisses assertions that "the 
conditions of the modern world" necessitate placement of the war power in the hands of the president. After all, in words that harken to the values and concerns of the framers, if "the current risk to national security is great, so is the risk of presidential miscalculation and aggrandizement-all the more reason for insisting that military decisions be thoroughly examined and approved by Congress. Contemporary presidential judgments need more, not less, scrutiny" (Fisher 2004, 262).

For Fisher, claims by champions of an executive war power are apt to place too great a premium on the need for speed and dispatch and the judgment of the president. The framers, Fisher notes, understood emergencies, which is why they vested in the executive the power to repel invasions. But defensive actions beyond defense of the nation and America troops, even if it involves our allies, require discussion and debate before risking the blood and treasure of the nation. If, as Fisher explains, the president perceives an emergency that is afoot in another part of the world, then he may decide to act and to seek from Congress retroactive authorization, which was the framers' solution to the problem of emergency, and the "procedure that Lincoln used in the Civil War" (Fisher 2004, 263; Adler 2012, 376-89).

\section{CONCLUSIONS}

The extension of a presidential power to initiate hostilities, whether in the eighteenth or twenty-first century, invites the very fears that induced the framers to vest in Congress, not the president, the power to go to war. Separation of powers issues are enduring, for they raise, fundamentally, the question of the repository of decision-making authority. For the framers in 1787 , as for Fisher in 2013, the fundamental value choices remain the same: executive unilateralism, featuring the judgment, temperament, and vision of a single person, versus discussion and debate, collective decision making, and checks and balances. Unless or until the Constitution is amended to grant to the president the authority to go to war, we can expect Lou Fisher to consistently defend the Constitution as it is. He is part of a grand tradition that embraces the virtues and values of constitutionalism, which was given eloquent voice by Justice Robert H. Jackson, who wrote in the landmark Steel Seizure Case: "With all its defects, delays and inconveniences, men have discovered no technique for long preserving free government except that the Executive be under the law, and that the law be made by parliamentary delibera- tions" (Youngstown Sheet and Tube Co. v. Sawyer, 655, quoted in Fisher, 2004, 281).

\section{REFERENCES}

Adler, David Gray. 1988. The Constitution and Presidential Warmaking: The Enduring Debate.” Political Science Quarterly 103: 1-36.

Adler, David Gray. 2003. "Constitution, Foreign Affairs and Presidential WarMaking: A Response to Professor Powell." Georgia State University Law Review 19: 947-1019.

Adler, David Gray. 2012. "The Framers and Executive Prerogative: A Constitutional and Historical Rebuke." Presidential Studies Quarterly 42: 376-89.

Bas v. Tingy. 1800.4 U.S. 4 (Dall.) 37.

Dean, John. 2007. Broken Government: How Republican Rule Destroyed the Legislative, Executive, and Judicial Branches. New York: Viking.

Draper, Theodore. 1995. "Capturing the Constitution: Presidents, a Scholar Contends, Have Simply Usurped the Power to Make War." New York Times Book Review, May 7. P1.

Elliot, Jonathan, ed. 1836. The Debates in the Several State Conventions on the Adoption of the Federal Constitution. Washington, DC: J. Elliot. 5 vols.

Farrand, Max, ed. 1966. The Records of the Federal Convention. New Haven, CT: Yale University Press, 4 vols.

Fisher, Louis. 1997. "Sidestepping Congress: Presidents Acting Under the UN and NATO." Case Western Reserve Law Review 47: 1237-79.

sity 2000. Congressional Abdication. College Station: Texas A\&M University Press.

- 2004. Presidential War Power, 2d ed. Lawrence: University Press of Kansas.

- 2005. "Judicial Review of the War Power." Presidential Studies Quarterly 35: 466-95.

. 2006. "From Presidential Wars to American Hegemony: The Constitution After 9/11." In The Presidency and the Challenge of Democracy, eds. Michael A. Genovese and Lori Cox Han, 23-52. New York: Palgrave MacMillan.

. 2007a. "Invoking Inherent Powers: A Primer." Presidential Studies Quarterly 37: 1-22.

_ 2007b. "The Law: Presidential Inherent Power: The 'Sole Organ' Doctrine." Presidential Studies Quarterly 37: 139-52.

. 2010. "The Law: When Wars Begin: Misleading Statements by Presidents." Presidential Studies Quarterly 40: 171-84.

. 2012. "The Law: Military Operations in Libya: No War? No Hostilities?" Presidential Studies Quarterly 42: 176-89.

Fisher, Louis, and David Gray Adler. 1998. "The War Powers Resolution: Time to Say Goodbye.” Political Science Quarterly 113: 1-20.

Little v. Barreme. 1804. 6 U.S. (2 Cr.) 170.

Talbot v. Seeman. 1801.4 U.S. (5 U.S.) 1.

United States v. Smith. 1806. 27 Fed. Cas. 1192 (C.C.N.Y. 1806) (No. 16,342).

Wormuth, Francis D., and Edwin Firmage. 1986. To Chain the Dog of War: The War Power in History and Law, 133-150. Dallas, TX: Southern Methodist University Press. 